\title{
KAMPUNG PENDIDIKAN DALAM PEMBERDAYAAN PARTISIPASIMASYARAKAT DESA YANG BERKARAKTER DAN BERDAYA SAING
}

\author{
Hasan \\ Universitas Negeri Jakarta \\ Email:
}

\begin{abstract}
Education is a process of improvement, strengthening, and refinement of all human potential and potential. Through education, life is expected to experience a change to a better direction. Although the government's efforts in equitable education have been done, but in reality there are still many Indonesian people, especially those who are in the countryside have not received education. Under these conditions, innovations needed to address the potential of rural areas that can support the assurance of increased knowledge through non-formal education for the sustainability of economic activities in rural areas. Therefore, Indonesia needs non-formal education innovation with local content that is Kampung Pendidikan. A social movement project initiated by the youth of the village (Inspirator) as a manifestation of awareness to improve the living standards of rural communities through character education and competitiveness that involves the community to take part in advancing education by learning and innovating by putting forward local content (Local Culture) to participate in contributing to build Indonesia. There are several Kampung Pendidikan programs: DIDIKMASYARAKAT (Collaboration and Synergy), DIDIKPEMUDA (Global Thinking, Acting Local), DIDIKKAMPUNG. Based on research conducted in Desa Kuajang, Binuang District Polewali Mandar Regency, West Sulawesi, the local community, desperately needs the presence of Kampung Pendidikan as a forum to build the potential of both the village of human resources, as well as natural resources.
\end{abstract}

Keywords: Kampung Pendidikan, rural, education.

\begin{abstract}
Abstrak. Pendidikan merupakan proses perbaikan, penguatan, dan penyempurnaan terhadap semua kemampuan dan potensi manusia. Melalui pendidikan, diharapkan kehidupan akan mengalami perubahan ke arah yang lebih baik. Walaupun upaya pemerintah dalam pemerataan pendidikan telah dilakukan, namun dalam kenyataannya masih banyak masyarakat Indonesia khususnya mereka yang berada di pedesaan belum mengenyam pendidikan. Dengan kondisi tersebut maka dibutuhkan inovasi penanganan potensi pedesaan yang dapat mendukung terjaminnya peningkatan pengetahuan melalui pendidikan nonformal demi keberlanjutan kegiatan perekonomian di pedesaan. Olehnya itu Indonesia perlu inovasi pendidikan nonformal yang bernuansa muatan lokal yaituKampung Pendidikan. Sebuah gerakan sosial project yang di inisiasioleh para pemuda kampung (Inspirator) sebagai wujud kepedulian untuk meningkatkan taraf hidup masyarakat desa melalui pendidikan berkarakter dan berdaya saing yang melibatkan masyarakat untuk ambil andil dalam memajukan pendidikan dengan cara belajar dan berinovasi dengan mengedepankan muatan lokal (Budaya Setempat) untuk ikut turut kontribusi membangun Indonesia. Ada beberapa program Kampung Pendidikan yaitu: DIDIKMASYARAKAT (Kolaborasi dan Sinergi), DIDIKPEMUDA (Berpikir Global, Bertindak Lokal), DIDIKKAMPUNG. Berdasarkan penelitian yang dilakukan di di Desa Kuajang, Kecamatan Binuang Kabupaten Polewali Mandar, Sulawesi Barat, masyarakat setempat, sangat membutuhkan hadirnya Kampung Pendidikan sebagai wadah untuk membangun potensi desa baik sumber daya manusia, maupun sumber daya alam.
\end{abstract}

Kata Kunci : Kampung Pendidikan, pedesaan, pendidikan.

\section{PENDAHULUAN}

Secara terminologis, pendidikan merupakan proses perbaikan, penguatan, dan penyempurnaan terhadap semua kemampuan dan potensi manusia. Pendidikan juga dapat diartikan sebagai suatu ikhtiar manusia untuk membina kepribadiannya sesuai dengan nilai-nilai dan kebudayaan yang ada dalam masyarakat. Dalam masyarakat yang peradabannya sangat sederhana sekalipun telah ada proses pendidikan. Oleh karena itu, tidak mengherankan jika sering dikatakan bahwa pendidikan telah ada semenjak munculnya peradaban manusia. Sebab, semenjak awal manusia diciptakan upaya membangun peradaban selalu dilakukan. Manusia mencitacitakan kehidupan yang bahagia dan sejahtera.

Melalui proses pendidikan yang benar dan baik maka cita-cita ini diyakini akan terwujud dalam realitas kehidupan manusiaSehingga dapat dikatakan betapa pentingnya suatu pendidikan 
dalam perjalanan hidup seorang manusia. Karena melalui pendidikan manusia akan lebih manuisiawi dan mampu mewujudkan suatu pribadi yang cakap. Melalui pendidikan, diharapkan kehidupan akan mengalami perubahan ke arah yang lebih baik. Pemerintah sendiri sudah menyebutkan dalam pembukaan Undan-Undang Dasar 1945 sebagaimana yang dikuip oleh Ary. H. Gunawan, bahwa "mencerdaskan kehidupan bangsa"(2000 : 46), dan selanjutnya dijabarkan dalam pasal 31 "Tiaptiap warga negara berhak mendapat pengajaran".

Hal ini membuktikan adanya langkah pemerataan pendidikan bagi seluruh warga negara Indonesia. Pemerataan kesempatan memperoleh pendidikan telah diupayakan pemerinah unuk menjangkau lapisan masyarakat di perkotaan dan pedesaan. Walaupun upaya pemerintah dalam pemerataan pendidikan telah dilakukan, namun dalam kenyataannya masih banyak masyarakat Indonesia khususnya mereka yang berada di pedesaan belum mengenyam pendidikan. Masyarakat pedesaan sendiri lebih identik dengan berbagai masalah yang harus dihadapi, diantaranya tidak tercapainya kebutuhan masyarakat pedesaan, wilayah tempat tinggal mereka yang terisolasi terhadap dunia luar maupun terhadap akses yang seharusnya mereka nikmati sebagai fasilitas negara terutama akses akan sumber daya terlebih pendidikan. Sehingga berdampak pada pertumbuhan dan kemajuan desa menjadi relatif lambat. Selain itu, mereka berpendapat sempit bahwa pendidikan bukanlah segalanya. Hal ini menyebabkan mereka mengalami krisis motivasi, keinginan dan kebutuhan pendidikan yang berujung pada rendahnya kualitas dan kuantitas pengetahuan masyarakat yang berkarakter dan berdaya saing. Padahal faktor utama membangun masyarakat negara yang ber Daya Saing tinggi adalah sumberdaya manusia (SDM) yang maju dan perkembangan Iptek. sementara masyarakat desa hanya bisa menguasai Teknologi sederhana, itupun baru bisa tersinergi jika infrastruktur desa dapat diwujudkan segera.

Dengan kondisi tersebut maka dibutuhkan inovasi penanganan penyediaan potensi pedesaan yang dapat mendukung terjaminnya peningkatan pengetahuan melalui pendidikan nonformal demi keberlanjutan kegiatan perekonomian di perdesaan Sehebat apapun reputasi kota, tanpa adanya desa, kota tidak akan pernah bisa maju seperti sekarang. Membangun desa adalah membangun masyarakat miskin, akan terwujud jika desa memiliki Sumberdaya Manusia terampil dan Iptek yang tepat.
Maka yang harus dilakukan adalah meningkatkan kemampuan dan kapasitas SDM Desa melalui pendidikan yang memadai dengan meningkatkan muatan lokal tanpa harus meninggalkan tuntutan muatan nasional yang antara lain dapat dilakukan melalui program pendidikan yang isi dan media penyampaiaanya dikaitkan dengan lingkungan alam pedesaan, lingkungan social, lingkungan budaya dan kebutuhan daerah sesuai prioritas muatan lokal yang memungkinkan SDM Desa akan terampil dan memiliki bekal untuk kehidupan.

Hal itu sesuai dengan sebuah istilah yang berasal dari salah seorang intelektual asal Maroko, yaitu Muhammad Abed Al-Jabiri yang mengatakan "Attajdidu mina dhdhahl"(2000 :102) perubahan harus berangkat dari tradisi kita, maksudnya bahwa perubahan bukan dengan meminjam tradisi orang ataupun bangsa lain. Olehnya itu Indonesia perlu inovasi pendidikan nonformal yang bernuansa muatan lokal yaitu"Kampung Pendidikan".

"Kampung Pendidikan"merupakan sebuah gerakan sosial project yang di inisiasioleh para pemuda kampung (Inspirator) sebagai wujud kepedulian untuk meningkatkan taraf hidup masyarakat desa melalui pendidikan berkarakter dan berdaya saing yang melibatkan masyarakat untuk ambil andil dalam memajukan pendidikan dengan cara belajar dan berinovasi dengan mengedepankan muatan lokal (Budaya Setempat) untuk ikut turut kontribusi membangun Indonesia.

Kampung Pendidikan merupakan inovasi pertama yang akan di hadirkan di Indonesia tepatnya di Desa Kuajang, Kecamatan Binuang Kabupaten Polewali Mandar. Desain pendidikan ini digunakan sebagai strategi dalam membangun perberdayaan partisipasi masyarakat yang berkarakter dan berdaya saing karena bermakna selalu mengupayakan peningkatan kesejahteraan masyarakat dan mendorong terciptanya sikap serta perilaku hidup individu yang menekankan keselarasan manusia dengan manusia, manusia dengan alam, dan manusia dengan Tuhan dalam melaksanakan hidup dan kehidupan. Desain pendidikan seperti ini berfungsi menjadi revolusi mental sebagai langkah strategis menuju Indonesia 2045 dan wahana sistemik dalam membangun masyarakat yang berkarakter dan berdaya saing.

Berdasarkan latar belakang masalah yang telah di jelaskan sebelumnya, maka penulis dapat merumuskan masalah yang akan dikaji dalam penelitian ini, yaitu : 
1. Bagaimana kegiatan Kampung Pendidikan dalam meningkatkan Pemberdayaan Partisipasi Masyarakat Desa yang Berkarakter dan Berdaya Saing?

2. Bagaimana masyarakat Desa khususnya Desa Kuajang menanggapi rencana pendirianKampung Pendidikan dalam memberikan Edukasi untuk meningkatkan Pemberdayaan Partisipasi Masyarakat Desa yang Berkarakter dan Berdaya Saing ?

\section{METODE PELAKSANAAN}

Jenis penelitian ini adalah deskriptif kualitatif yaitu menganalisi dan mendeskripsikan hasil kajian mengenai kehidupan masyarakatdalam mengembangkan pengetahuan melalui pendidikan berbasis muatan lokal.
Penelitian ini diawali dari penentuan masalah yang akan dikaji. Setelah masalah ditentukan, penulis memikirkan ide terhadap penyelesaian masalah tersebut. Kemudian penulis melakukan wawancara terhadap narasumber untuk mendapatkan informasi yang berkaitan dengan ide tersebut. Kemudian informasi hasil wawancara dianalisis,

Hasil analisis tersebut ditulis dan dikembangkan melalui studi dokumentasi seperti referensi sumber buku, jurnal dan internet seperti website, e-jurnal, dan e-book. Setelah itu penulis kemudian melanjutkan pembuatan karya tulis hingga selesai.Gambar rancang penulisan digambarkan sebagai berikut: .

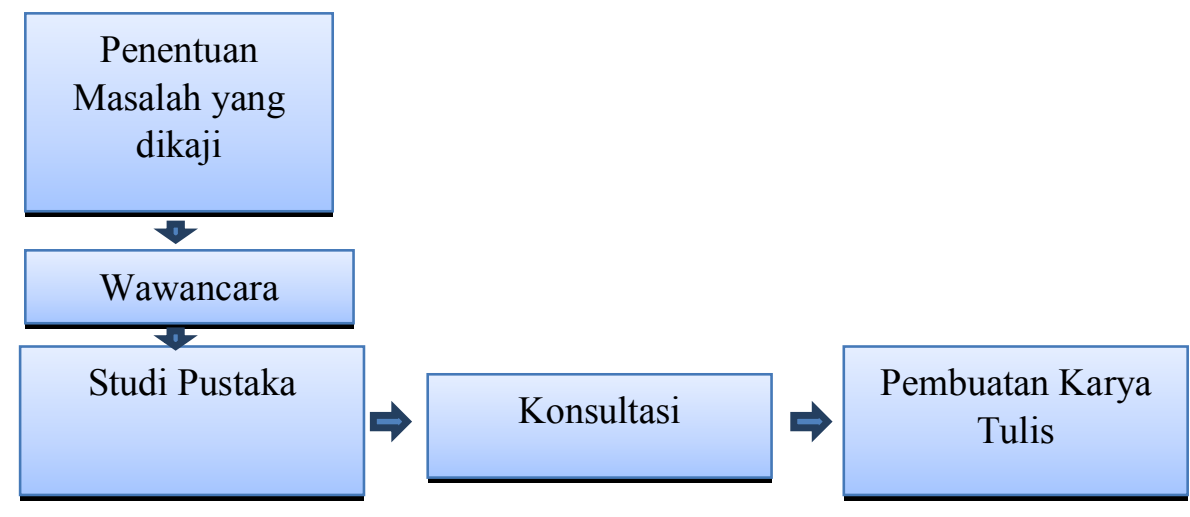

Gambar 1. Rencangan Penulisan

Pengumpulan data dilakukan dengan dua metode yaitu teknik wawancara dan pencatatan dokumen yaitu 1) Wawancara dalam hal ini dilakukan dengan mewawancarai secara langsung narasumber yang berkaitan dengan penulisan, sehingga didapatkan data secara kualitatif untuk mendukung penulisan. 2) Studi pustaka dalam hal ini penulis mencari sumber-sumber referensi untuk mendukung penelitian dari buku, website, journal, e-book, e- journal dan berita, sehingga data yang didapatkan semakin akurat.

\section{HASIL DAN PEMBAHASAN}

Bagaimana kegiatan Kampung Pendidikan dalam meningkatkan Pemberdayaan Partisipasi Masyarakat Desa yang Berkarakter dan Berdaya Saing ?

Pemberdayaan digunakan sebagai konsep alternatif untuk meningkatkan kemampuan dan martabat masyarakat agar terlepas dari jerat kemiskinan dan keterbelakangan. Atau, dengan kata lain, menjadikannya "ber-power" atau dalam istilah Kartasasmita, memandirikan, memberdayakan dan memampukan masyarakat.

Pemberdayaan senantiasa berkaitan dengan penggalian dan pengembangan potensi masyarakat, menurut Kartasasmita bahwa setiap manusia dan masyarakat memiliki potensi yang dapat dikembangkan, sehingga pemberdayaan adalah upaya untuk membangun daya itu dengan mendorong, memberikan motivasi dan membangkitkan kesadaran akan potensi yang dimiliki serta untuk mengembangkannya. Dengan kata lain, memberdayakan masyarakat adalah memampukan dan memandirikan masyarakat. Oleh karena itu ia mengatakan bahwa pemberdayaan harus terarah (targeted), ditujukan langsung kepada yang memerlukan (berbasis kebutuhan), langsung mengikutsertakan dan dilaksanakan oleh masyarakat yang menjadi sasaran program (partisipatif), menggunakan pendekatan kelompok karena secara sendirisendiri masyarakat miskin sulit dapat memecahkan masalah-masalah yang dihadapinya. Di sisi lain Kartasasmita 
mengatakan upaya memberdayakan masyarakat dapat dilihat dari 3 sisi yaitu :

1. Menciptakan suasana atau iklim yang memungkinkan potensi masyarakat berkembang (enabling). Titik tolaknya adalah pengenalan bahwa setiap manusia, setiap masyarakat memiliki potensi yang dapat dikembangkan.

2. Memperkuat potensi atau daya yang dimiliki oleh masyarakat (empowering). dalam rangka ini diperlukan langkah-langkah lebih positif, selain dari hanya menciptakan iklim dan suasana. perkuatan ini meliputi langkahlangkah nyata dan menyangkut penyediaan berbagai masukan (input) serta membuka akses ke berbagai peluang (opportunities) yang membuat masyarakat menjadi makin berdaya. ketiga,

3. Memberdayakan mengandung pula arti melindungi. Dalam proses pemberdayaan idealnya harus dicegah yang lemah menjadi bertambah lemah karena kekurangberdayaan dalam menghadapi yang kuat.

Pemberdayaan merupakan suatu bentuk upaya memberikan kekuatan, kemampuan, keterampilan, pengetahuan dan berbagai bentuk inovasi kreatif sesuai dengan kondisi, yang secara potensial dimiliki. Memberdayakan masyarakat menurut Kartasasmita (2010:27) adalah upaya untuk meningkatkan harkat dan martabat lapisan masyarakat yang dalam kondisi sekarang tidak mampu untuk melepaskan diri dari perangkap kemiskinan dan keterbelakangan. Untuk menunjang kesemua itu diperlukan pengetahuan masyarakat.

Untuk mencapai perberdayaan partisipasi masyarakat maka perlu Meningkatkan kapasitas Iptek. Desa tak terlepas dari adanya hubungan IPTEK dan kemiskinan. Ilmu pengetahuan, teknologi yang memiliki kaitan struktur yang jelas. Ilmu pengetahuan dan teknologi merupakan dua hal yang tak terpisahkan dalam peranannya untuk memenuhi kebutuhan insani. Ilmu pengetahuan digunakan untuk mengetahui "apa" sedangkan teknologi mengetahui "bagaimana". Ilmu pengetahuan sebagai suatu badan pengetahuan sedangkan teknologi sebagai seni yang berhubungan dengan proses produksi, berkaitan dalam suatu sistem yang saling berinteraksi. Teknologi merupakan penerapan ilmu pengetahuan, sementara teknologi mengandung ilmu pengetahuan di dalamnya. Perubahan teknologi yang cepat dapat mengakibatkan perubahan struktur dan pola kemiskinan, karena terjadi perubahan sosial yang fundamental. Olehnya itu dengan hadirnya kampung pendidikan menjadi solusi alternatif untuk menjawab tantangan tersebut.

Meningkatkan daya saing masyarakat desa melalui pendidikan menjadi sorotan utama Kampung Pendidikan, Menurut Muhammad Saroni (2011: 10) bahwa, "Pendidikan merupakan suatu proses yang berlangsung dalam kehidupan sebagai upaya untuk menyeimbangkan kondisi dalam diri dengan kondisi luar diri. Proses penyeimbangan ini merupakan bentuk survive yang dilakukan agar diri dapat mengikuti setiap kegiatan yang berlangsung dalam kehidupan." Sedangkan menurut Yahya Khan (2010: 1) "Pendidikan merupakan sebuah proses yang menumbuhkan, mengembangkan, mendewasakan, menata, dan mengarahkan". Pendidikan juga berarti proses pengembangan berbagai macam potensi yang ada dalam diri manusia agar dapat berkembang dengan baik dan bermanfaat bagi dirinya dan juga lingkungannya. Kemudian menurut Notoatmodjo (2010:24) pendidikan adalah upaya persuasi atau pembelajaran kepada masyarakat, agar masyarakat mau melakukan tindakan tindakan (praktik) untuk memelihara (mengatasi masalahmasalah), dan meningkatkan kesehatannya. Perubahan atau tindakan pemeliharaan dan peningkatan kesehatan yang dihasilkan oleh pendidikan kesehatan ini didasarkan kepada pengetahuan dan kesadarannya melalui proses pembelajaran, sehingga perilaku tersebut diharapkan akan berlangsung lama (long lasting) dan menetap (langgeng), karena didasari oleh kesadaran.

Metode pada Kampung Pendidikan ini mengajarkan masyarakat untuk selalu dekat dengan situasi konkrit yang mereka hadapi sehari-hari. Tempat dan jadwal Jenis program pendidikan keterampilan yang dibina secara cermat disesuaikan dengan waktu, kebutuhan dan motivasi, yang penerapannya bisa dilaksanakan secara fisik dan ekonomis dalam keadaan khas di masyarakat dengan khasanah bahasa serta gaya belajar kelompok yang sesuai, sehingga dapat melaksanakan evaluasi secara langsung untuk mengadakan penyesuaian dan penyempurnaan tujuan-tujuan pendidikan pemberdayaan masyarakat. Dengan kata lain model pendidikan ini mengajak kepada kita semua untuk selalu dekat dan menjaga keadaan sekitar yang bersifat nilai yang berada di dalam lokal masyarakat tersebut. Model pembelajaran pada "Kampung Pendidikan" ini dilaksanakan melalui: 
DIDIKMASYARAKAT (Kolaborasi dan Sinergi):

DidikMasyarakat (DIMAS) melalui pendidikan karakter berbasis muatan lokal atau penerapan budaya dimaksudkan untuk meningkatkan disiplin,demokratis, bertanggung jawab, menghargai, jiwa gotong royong, kebersamaan, saling terbuka satu sama lain, menumbuhkembangkan jiwa kekeluargaan, membangun komunikasi yang lebih baik, serta tanggap dengan perkembangan dunia luar sehingga sikap dan juga prilaku sumber daya manusia mampu menghadapi tantangan dimasa yang akan datang.

Pemberdayaan yang terkait dengan masyarakat merupakan salah satu strategi efektif dalam pembinaan dan pengembangan karakter dan daya saing. Konsep implementasi pendidikan dan pemberdayaan masyarakat dilakukan melalui:

Tabel 1. Program Pendidikan Karakter dan Pemberdayaan Partispasi masyarakat dalam meningkatkan Daya Saing melalui DIDIKMASYARAKAT pada Kampung Pendidikan

\begin{tabular}{cccc}
\hline Program & Moral/ Pelaksanaan & Penyebab & Hasil \\
\hline Pendidikan Karakter & &
\end{tabular}

1. Hubungan antara manusia dangan Tuhan

2. Hubungan Manusia dengan manusia

3. Hubungan Manusia dengan Lingkungan
Bertaqwa pada Tuhan yang Maha Esa.

\section{Disiplin}

Demokratis

Bertanggungjawab

Menghargai

Gotong Royong

Cinta Tanah Air
Tanpa pendidikan

Karakter

Tanpa pendidikan

Karakter

Tanpa pendidikan

Karakter

Tanpa pendidikan

Karakter

Tnpa pendidikan

Karakter

Tanpa pendidikan

Karakter

Tanpa pendidikan

Karakter

Akan Meninggalkan setiap perintah agama dan tidak berbuat maksiat.

Melangar setiap peraturan yang berlaku, melanggar etika sosial / masyarakat setempat, dll. Tidak mau mendengarkan pendapat orang lain, tidak toleran terhadap teman, tidak mau menerima kritik dan saran dari orang lain, dll. Mencari-cari kesalahan orang lain, lari dari tanggung jawab, dll.

Berprilaku tidak santun dalam setiap kontak sosial, tidak mempunyai rasa hormat kepada sesama masayrakat dan tidak menghargai karya orang lain. Tidak bersedia membantu orang lain dan mengabaikan kerja sama

Merusak lingkungan Alam, tidak merasa memiliki lingkungan serta akan merusak flora dan fauna Indonesia.

\section{Pemberdayaan}

\section{Masyarakat}

1. Peningkatan Keberdayaan Masyarakat Perdesaan

\section{Dengan} memfasilitasi dan pendampingan berkelanjutan dalam perencanaan, pembangunan, dan pengelolaan desa

2. Dengan penguatan Keberdayaan lembaga adat dan Desa Adat, perlindungan hakhak masyarakat adat
Tanpa Ilmu

Pengetahuan

Kemampuan masyarakat dalam membangun suatu kemitraan dengan berbagai pihak akan mengalami kesulitan

Penguatan kapasitas masyarakat untuk mampu mandiri memfasilitasi kegiatan masyarakat dalam wilayahnya akan mengalami kesulitan 


\begin{tabular}{|c|c|c|c|}
\hline Program & Moral/ Pelaksanaan & Penyebab & Hasil \\
\hline & $\begin{array}{l}\text { sesuai dengan } \\
\text { perundangan yang } \\
\text { berlaku } \\
\text { 3. Dengan penguatan } \\
\text { sosial budaya } \\
\text { masyarakat dan } \\
\text { keadilan gender } \\
\text { (kelompok wanita, } \\
\text { pemuda, anak, dan } \\
\text { TKI) }\end{array}$ & & \\
\hline $\begin{array}{ll}\text { 2. } & \text { Pendampingan } \\
\text { Aparat } \\
\text { Pemerintah Desa }\end{array}$ & $\begin{array}{l}\text { Penguatan dan } \\
\text { pemberian penjelasan } \\
\text { kepada ketua-ketua RT, } \\
\text { RW, kepala dusun / } \\
\text { lingkungan dan atau } \\
\text { tokoh tentang prioritas } \\
\text { program desa, refleksi } \\
\text { kebutuhan warga RT, } \\
\text { RW dan dusun akan apa } \\
\text { yang seyogyanya mereka } \\
\text { lakukan terkait masalah } \\
\text { komunal mereka. } \\
\text { Penjelasan ini sifatnya } \\
\text { sebatas memberi } \\
\text { gambaran "pencerahan", } \\
\text { membangun kesiapan } \\
\text { dalam memberikan } \\
\text { masukan atau usulan } \\
\text { program, bukan } \\
\text { mengarahkan }\end{array}$ & $\begin{array}{l}\text { Tanpa Ilmu } \\
\text { Pengetahuan }\end{array}$ & $\begin{array}{l}\text { Masyarakat akan sulit dalam } \\
\text { meningkatkan pemahaman dan } \\
\text { pengawasan aparatur } \\
\text { pemerintahan desa di bidang } \\
\text { administrasi (penguatan basis } \\
\text { struktural). } \\
\text { Masyarakat akan sulit } \\
\text { memastikan dokumen-dokumen } \\
\text { terkait penyelenggaraan } \\
\text { pemerintahan desa yang baik } \\
\text { serta sulit untuk update dan } \\
\text { asertif terhadap masalah terkini } \\
\text { masyarakat desa sedangkan hal } \\
\text { Ini diperlukan } \\
\text { sebagai inputkebijakan } \\
\text { pemerintahan desa }\end{array}$ \\
\hline $\begin{array}{l}\text { 3. Pengembangan } \\
\text { Ekonomi } \\
\text { Perdesaan }\end{array}$ & $\begin{array}{l}\text { a. Meningkatkan } \\
\text { kegiatan ekonomi desa } \\
\text { yang berbasis } \\
\text { komoditas unggulan, } \\
\text { melalui pengembangan } \\
\text { rantai nilai, } \\
\text { peningkatan } \\
\text { produktivitas, serta } \\
\text { penerapan ekonomi } \\
\text { hijau } \\
\text { b. Menyediakan dan } \\
\text { meningkatkan sarana } \\
\text { dan prasarana } \\
\text { produksi, pengolahan, } \\
\text { dan pasar desa } \\
\text { c. Meningkatkan akses } \\
\text { masyarakat desa } \\
\text { terhadap modal usaha, } \\
\text { pemasaran dan } \\
\text { informasi pasa } \\
\text { mengembangkan } \\
\text { lembaga pendukung } \\
\text { ekonomi desa seperti } \\
\text { koperasi, dan } \\
\text { BUMDesa, dan } \\
\text { lembaga ekonomi } \\
\text { mikro lainnya }\end{array}$ & $\begin{array}{l}\text { Tanpa Ilmu } \\
\text { Pengetahuan }\end{array}$ & $\begin{array}{l}\text { Pengembangan produk } \\
\text { masyarakat tidak akan } \\
\text { bervariasi sehingga sulit untuk } \\
\text { memajukan usaha untuk } \\
\text { memenuhi kebutuhan ekonomi. }\end{array}$ \\
\hline
\end{tabular}




\begin{tabular}{|c|c|c|c|}
\hline Program & Moral/ Pelaksanaan & Penyebab & Hasil \\
\hline penyuluhan & $\begin{array}{l}\text { dan penyuluhan } \\
\text { tentang pentingnya } \\
\text { pendidikan karakter } \\
\text { dengan caraPembuatan } \\
\text { papan pintar } \\
\text { menggunakan bantuan } \\
\text { spanduk ukuran 1x1 m } \\
\text { yang diletakkan di } \\
\text { depan rumah masing- } \\
\text { masing.(setiap } \\
\text { masyarakat akan } \\
\text { membuat quote } \\
\text { tentang ajakan/pesan } \\
\text { pendidikan). } \\
\text { b. Pemasangan Slogan } \\
\text { ajakan/himbauantentan } \\
\text { g pendidikan disetiap } \\
\text { sudut jalan. } \\
\text { Pemasangan sumber } \\
\text { informasi (Peta } \\
\text { Kampung) dan } \\
\text { Pemasangan Umbul- } \\
\text { Umbul, 7K dan 5S }\end{array}$ & Pengetahuan & $\begin{array}{l}\text { pelatihan akan di anggap } \\
\text { sebagai kegiatan yang menyita } \\
\text { waktu dan sia-sia. }\end{array}$ \\
\hline $\begin{array}{ll}\text { 5. } & \text { Pemberian } \\
& \text { penghargaan }\end{array}$ & $\begin{array}{l}\text { Pemberian penghargaan } \\
\text { kepada para tokoh-tokoh } \\
\text { atau orang tua yang telah } \\
\text { menunjukkan } \\
\text { komitmennya dalam } \\
\text { memajukan pendidikan } \\
\text { dan membangun karakter } \\
\text { di lingkungan keluarga } \\
\text { dan lingkungan } \\
\text { masyarakat dengan } \\
\text { caraPembuatan papan } \\
\text { biografi menggunakan } \\
\text { spanduk untuk para } \\
\text { pejuang atau yang sudah } \\
\text { berjasa dalam memajukan } \\
\text { kampung tersebut baik } \\
\text { yang sudah meninggal } \\
\text { maupun yang masih } \\
\text { hidup. }\end{array}$ & $\begin{array}{l}\text { Tanpa Ilmu } \\
\text { Pengetahuan }\end{array}$ & $\begin{array}{l}\text { Pemberian penghargaan akan di } \\
\text { anggap sebagai kegiatan yang } \\
\text { ria dan tidak penting. }\end{array}$ \\
\hline
\end{tabular}

Berdasarkan tabel 1 di atas, disimpulkan bahwa dalam kehidupan bermasyarakat, perlu terdapat moral taqwa, jujur, disiplin, demokratis, gotong royong, adil, bertanggung jawab, menghargai, cinta tanah air dan lain sebagainya, jika tanpa pendidikan karakter akan menyebabkan terjadinya perilaku menyimpang. Maka, diperlukan sebuah upaya yang tepat untuk mengembangkan moral dalam kehidupan masyarakat dalam mengatasi perilaku menyimpang ini. Upaya untuk mengatasi perilaku menyimpang dalam masyarakat, bisa dilakukan dengan meningkatkan karakter dan pengetahuan masayarakat. Helden (dalam Sjarkawi, 2008: 28) menyatakan "karakter sebagai suatu kepekaan dalam pikiran, perasaan, dan tindakan dibandingkan dengan tindakan lain yang tidak hanya berupa kepekaan terhadap prinsip dan aturan". Selanjutnya Atkinson (1969 dalam Sjarkawi, 2008: 28)menyatakan bahwa: "karakter merupakan sifat dalam memandang tentang baik buruk, benar salah, apa yang dapat dan tidak dapat dilakukan", merupakan ciri dari masyarakat yang memiliki karakter.

Konsep pemberdayaan masyarakat, pada mulanya merupakan gagasan yang ingin menempatkan manusia sebagai subyek dari dunianya sendiri. Oleh karena itu, wajar apabila konsep ini menampakkan kecenderungan bahwa pemberdayaan menekankan pada proses 
pemberian atau mengalihkan sebagian kekuasaan, kekuatan atau kemampuan (power)kepada masyarakat, organisasi atau individu agar menjadi lebih berdaya. Implikasi dari konsepsi ini adalah pertama, penciptaan ruang bagi bekerjanya peran-peran lokal, kedua, peran aktoraktor lokal dalam menafsir "nasib sendiri" dan "nasib bersama", ketiga, "kewenangan komunitas" yakni kepada warga desa atau "desa selaku komunitas/ entitas politik yang satu".

Dengan mengikuti pemikiran ini, maka kegiatan pemberdayaan merupakan kegiatan yang "embedded" (menyatu) dengan kegiatan pembangunan (desa) dan merujuk pada satu tujuan atau misi bersama yakni kemampuan dan kemandirian. Pemberdayaan (kemampuan dan kemandirian) merupakan kunci dan prasyarat dari aktivitas masyarakat desa dalam membangun. Konsep "pemberdayaan" ini, mengikuti pemikiran Chambers yang dikutip Kartasasmita (2010 : 31), merangkum nilai-nilai sosial dan mengikuti paradigma pembangunan yang bersifat "people centered" (berpusat pada masyarakat), participatory (partisipatif)

dan sustainable (berkelanjutan).

Oleh sebab itu, melalui DIDIKMASYARAKAT pada Kampung Pendidikan menjadi wadah pemberdayaan untuk menghasilkan masyarakat berkarakter dan berdaya saing. Masyarakat akan diberdayakandalam berbagai kegiatan. Kedua kunci pemikiran ini mengandung makna bahwa pemberdayaan partisipatif bagi masayarakat" dalam rangka pembangunan berbasis masyarakat (people centered development), memerlukan kebersamaan dan tafsir bersama akan nasib bersama warga desa (common sense), yang memperhatikan kebersamaan dalam keragaman (pluralitas) dan kekhasan lokal, kearifan lokal, untuk bersama-sama menggalang kekuatan.

\section{DIDIKPEMUDA (Berpikir Global, Bertindak Lokal)}

DidikPemuda (DIPA) dimaksudkan untuk menanamkan nilai-nilai nasionalisme kepada para pemuda serta membina kecerdasan sosial agar mampu berpikir kritis, analitis, kreatif,inovatif, berwatak dan berkepribadian luhur, bersikap ilmiah dalam cara memandang, menganalisa serta menelaah kehidupan nyata yang di hadapinya sehingga dapat membantu membuat informasi dan keputusan yang beralasan untuk kepentingan publik sebagai warga masyarakat yang beragam budaya dan bertanggung jawab terhadap lingkungannya serta mencintai budayanya.

Tabel 2. Program Pendidikan Karakter dan Pemberdayaan Partispasi Masyarakat dalam Meningkatkan Daya Saing melalui DIDIKPEMUDA pada Kampung Pendidikan

\begin{tabular}{|c|c|c|c|}
\hline Program & Moral/ Pelakasanaan & Penyebab & Hasil \\
\hline \multicolumn{4}{|l|}{$\begin{array}{l}\text { Pendidikan } \\
\text { Karakter }\end{array}$} \\
\hline $\begin{array}{l}\text { 1. Hubungan } \\
\text { antara manusia } \\
\text { dangan Tuhan }\end{array}$ & $\begin{array}{l}\text { Bertaqwa pada Tuhan } \\
\text { yang Maha Esa. }\end{array}$ & $\begin{array}{l}\text { Tanpa } \\
\text { pendidikan } \\
\text { Karakter }\end{array}$ & $\begin{array}{l}\text { Meninggalkan setiap perintah agama } \\
\text { dan berbuat maksiat. }\end{array}$ \\
\hline \multirow[t]{5}{*}{$\begin{array}{l}\text { 2. Hubungan } \\
\text { Manusia } \\
\text { dengan manusia }\end{array}$} & Disiplin & $\begin{array}{l}\text { Tanpa } \\
\text { pendidikan } \\
\text { Karakter }\end{array}$ & $\begin{array}{l}\text { Melangar setiap peraturan yang } \\
\text { berlaku, melangar etika sosial / } \\
\text { masyarakat setempat, dll. }\end{array}$ \\
\hline & Demokratis & $\begin{array}{l}\text { Tanpa } \\
\text { pendidikan } \\
\text { Karakter }\end{array}$ & $\begin{array}{l}\text { Tidak mau mendengarkan pendapat } \\
\text { orang lain, tidak toleran terhadap } \\
\text { teman, tidak mau menerima kritik dan } \\
\text { saran dari orang lain, dll. }\end{array}$ \\
\hline & Bertanggungjawab & $\begin{array}{l}\text { Tanpa } \\
\text { pendidikan } \\
\text { Karakter }\end{array}$ & $\begin{array}{l}\text { Mencari-cari kesalahan orang lain, lari } \\
\text { dari tanggung jawab, dll. }\end{array}$ \\
\hline & Menghargai & $\begin{array}{l}\text { Tanpa } \\
\text { pendidikan } \\
\text { Karakter }\end{array}$ & $\begin{array}{l}\text { Berprilaku tidak santun dalam setiap } \\
\text { kontak sosial, tidak mempunyai rasa } \\
\text { hormat kepada sesama masayrakat dan } \\
\text { tidak menghargai karya orang lain. }\end{array}$ \\
\hline & Gotong Royong & Tanpa & Tidak bersedia membantu orang lain \\
\hline
\end{tabular}




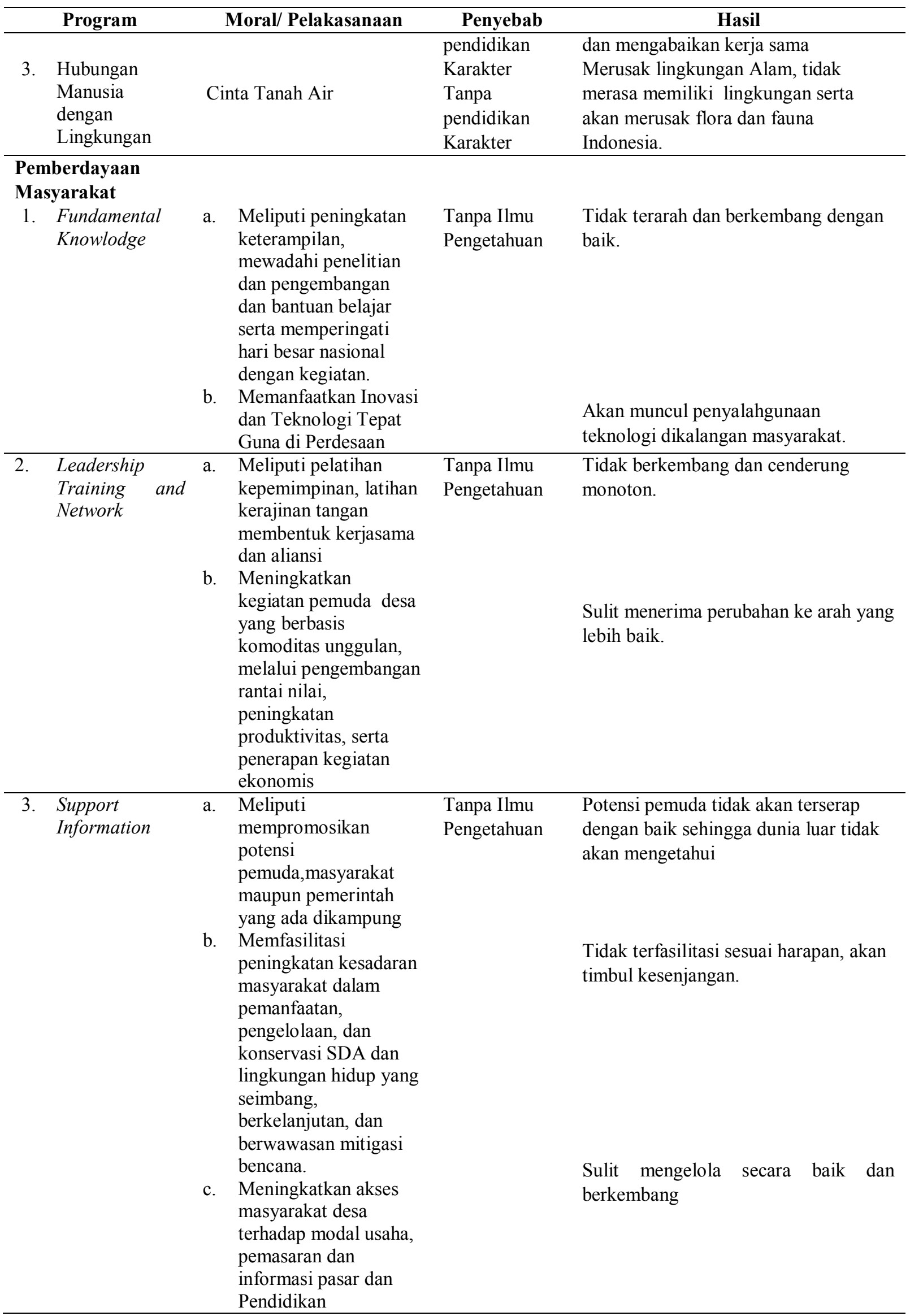

Berdasarkan tabel 2 dapat menjelasakan bahwa perilaku menyimpang merupakan masalah besar yang sedang dihadapi oleh Bangsa Indonesia. Hal ini diperkuat dengan teori 
behaviordalam

(Boeree,2009:56)

yang

menyatakanbahwa perilaku menyimpang itu dapatdikatakan sebagai behavior disorderyang artinya perilaku menyimpang itu terbentuk karena adanya stimulus negatif yang mempengaruhi individu sehingga menimbulkan suatu respon dalam dirinya untuk melakukan hal tersebut dan mewujudkanya dalam bentuk perilaku yang menyimpang. Generasi muda sebagai generasi penerus bangsa, banyak yang terlibat dalam perilaku menyimpang. Tawuran antar pelajar, penggunaan narkoba, perilaku seks diluar nikah, tindak kriminal dan masih banyak lagi lainnya yang menyimpang, kini menjadi hal biasa dikalangan pelajar. Padahal perilaku yang mereka lakukan ini, memberikan dampak yang buruk terhadap diri sendiri dan orang lain. Selain itu, perilaku menyimpang ini juga akan dapat membawa dampak buruk terhadap bangsa dan negara.

Ketidakmampuan pemuda dalam mengendalikan diri ke arah yang lebih baik, merupakan faktor dari kurangnya karakter dan daya saing sehingga terjadinya perilaku menyimpang. Beberapa penelitian, juga menjelaskan bahwa, diri seseorang yang tidak dapat dikendalikan (karakter diri rendah) akan mengakibatkan terjadinya perilaku menyimpang. Pendidikan karakter yang semakin hari terkikis oleh arus globalisasi yang sangat kuat sehinga nilai-nilai karakter dari muatan lokal tersebut semakin ditingalkan ini terjadi pada pemuda yang mengalami masalah moral.

Jika hal ini tidak dikendalikan, maka akan terjadi suatu kebiasaan untuk melakukan tindakan-tindakan yang bersifat negatif (perilaku menyimpang). Maka perlu dilakukan pemberdayaan pemuda agar mampu keluar dari prilaku-prilaku yang menyimpan. Melalui peranan pemuda diharapkan terciptanya pertumbuhan dan perkembangan desa sehingga dengan itu desa dapat menjadi mandiri dan mampu menghadapi persaingan lokal, nasional maupin global yang telah menanti. Daya saing masyarakat desa akan tercapai apabila desa telah mengalami kedewasaan baik dari segi pembangunan infrastruktur dan sumber daya manusia yang maju.

Oleh sebab itu, melalui DIDIKPEMUDA pada Kampung Pendidikan menjadi wadah pemberdayaan untuk merangsangpara pemuda berpikir globaldengan karakter lokal yang kuat sehingga mampu menyesuikan dengan kemajuan daya saing zaman.

\section{DIDIKKAMPUNG}

DidikKampung (DIKA) sebagai usaha untuk meningkatkan pengetahuan masyarakat dengan lingkungan yang mendukung dalam penjaminanmutu pendidikan ataupemerataan kesempatan untuk memperoleh pendidikan, ataupun sebagai usaha untuk meningkatkan efisiensi pembelajaran. Inovasi ini dimaksudkan untuk menambah wawasandan pengetahuan dalam meningkatkan kinerja dan menguatkan kerjasama dan kebersamaan dalam masyarakat.Menurut Soerjono Soekanto (2006: 66) kerjasama merupakan suatu usaha bersama antara orang perorangan atau kelompok untuk mencapai tujuan tertentu. Pendapat tersebut sudah jelas mengatakan bahwa kerjasama merupakan bentuk hubungan antara beberapa pihak yang saling berinteraksi untuk mencapai tujuan bersama. Maka dari itu sangat diperlukan kerjasama dan kebersamaan untuk meningkatkan pengetahuan masyarakat.

Berdasarkan tabel 3 Strategi pencapaian desa mandiri dengan masyarakat yang berkarakter dan berdaya saing, partisipatif dan berdaya sebagaimana amanat UU Nomor 6 Tahun 2014 tentang Desa, dilakukan dengan fokus pada pemberdayaan masyarakat yang diselenggarakan dengan strategi partisipatif dalam koridor good village governance (kepemerintahan desa yang baik). Secara operasional, diperlukan penumbuhkembangan semangat membangun diri bersama (togetherness in collective action), penguatan modal sosial dalam paradigma Desa Membangun. Namun, bagaimana melakukan pemberdayaan dan peningkatan kapasitas masyarakat desa berbasis partisipasi. 
Tabel 3. Program Pemberdayaan Partispasi Masyarakat dalam Meningkatkan Daya Saing melalui DIDIKKAMPUNG pada Kampung Pendidikan

\begin{tabular}{|c|c|c|}
\hline Program & Pelaksanaan & Hasil \\
\hline $\begin{array}{l}\text { Inventarisasi potensi } \\
\text { dan sumberdaya desa }\end{array}$ & $\begin{array}{ll}\text { a. } & \text { Pemetaan dan analisa sosial serta } \\
\text { pendokumentasian desa yang dapat } \\
\text { didayagunakan secara efektif-efisien } \\
\text { oleh penyelenggara pemerintahan desa } \\
\text { (kepala desa, perangkat dan BPD serta } \\
\text { masayarakat } \\
\text { b. Membuat peta desa yang memuat data } \\
\text { dan informasi geospasial desa, meliputi } \\
\text { potensi wilayah, demografi, yang tersaji } \\
\text { dengan baik dan mudah diakses, } \\
\text { melengkapi pemetaan sosial }\end{array}$ & $\begin{array}{l}\text { Masyarakat akan turut andil dalam } \\
\text { menentukan kemajuan desa. Dan } \\
\text { informasi tentang Desa bagi dunia } \\
\text { luar akan terbuka dengan adanya } \\
\text { info-info tentang desa }\end{array}$ \\
\hline $\begin{array}{l}\text { Pemeliharaan } \\
\text { integritas dalam } \\
\text { pelayanan publik }\end{array}$ & $\begin{array}{l}\text { a. Mengaktifkan Jam Balajar Kampung } \\
\text { b. Membuat Camp Bahasa (Bahasa } \\
\text { Daerah, Bahasa Inggris, Bahasa Arab } \\
\text { dan Bahasa Indonesia } \\
\text { c. Mengaktifkan permainan traditonal } \\
\text { d. Membuat perpustakaan kampung } \\
\text { e. Membuat kelas inspirasi dan kelas } \\
\text { f. Motivasi } \\
\text { g. } \text { ' Dembuat taman baca dan taman } \\
\text { h. } 1 \text { Sarjana 1 kampung }\end{array}$ & $\begin{array}{l}\text { Desa akan menjadi lingkungan } \\
\text { yang nyaman bagi para } \\
\text { masayarakat dalam beraktivitas } \\
\text { sehingga akan memacu } \\
\text { masayarakat untuk selalu upgrade } \\
\text { pengetahuan }\end{array}$ \\
\hline
\end{tabular}

Olehnya itu dengan adanya perencanaan, pelaksanaan dan DIDIKKAMPUNG pada Kampung Pendidikan pertanggungjawabkan serta mengevaluasi secara yang terdapat di Desa menjadi wadah untuk langsung sangat diperlukan sebagai upaya melakukan kegiatan pelatihan dan pendampingan peningkatan kualitas diri dan kesejahteraan dalam konteks penyelenggaraan pemerintahan ekonomi. Dan menurut pendiri dari kampung dan pembangunan desa yang mampu pendidikan bahwa dalam perencanaan meningkatkan kapasitas pemerintah desa dalam pembangunan seperti ini, terdapat dua pihak yang menyusun dan melaksanakan program memiliki hubungan yang sangat erat yaitu pembangunan desa yang bertumpu pada pertama, pihak yang memberdayakan (community pemberdayaan masyarakat desa.

Bagaimana masyarakat Desa khususnya Desa Kuajang menaggapi Kampung Pendidikan dalam memberikan edukasi untuk meningkatkan Pemberdayaan Partisipasi Masyarakat Desa yang Berkarakter dan Berdaya Saing?

Berdasarkan hasil catatan penelusuran dengan cara observasi dan wawancara dengan masyarakat Desa Kuajang Kecamatan Binuang terhadap rencana mendirikan Kampung pendidikan dalam memberikan edukasi kepada masyarakat direspon sangat baik, karena masyarakat dan aparat desa menilai tujuan program yang mengikutsertakan masyarakat dalam proses pendidikan untuk pemberdayaan masyarakat dinilai efektif dan efisien karena sesuai dengan kebutuhan dan kemampuan masyarakat.

Meningkatkan keberdayaan (empowering) masyarakat dengan bersama melakukan worker) dan kedua, pihak yang diberdayakan (masyarakat). Antara kedua pihak harus saling mendukung sehingga masyarakat sebagai pihak yang akan diberdayakan bukan hanya dijadikan objek, tapi lebih diarahkan sebagai subjek (pelaksana). Hal ini sesuai dengan pendapat dari Pemberdayaan menurut Suhendra (2006:74-75) adalah "suatu kegiatan yang berkesinambungan, dinamis, secara sinergis mendorong keterlibatan semua potensi yang ada secara evolutif dengan keterlibatan semua potensi”.

\section{SIMPULAN}

Pendidikan merupakan proses perbaikan, penguatan, dan penyempurnaan terhadap semua kemampuan dan potensi manusia. Sehingga dapat dikatakan betapa pentingnya pendidikan dalam perjalanan hidup seorang manusia. Namun dalam kenyataannya masih banyak masyarakat Indonesia khususnya mereka yang berada di pedesaan belum mengenyam pendidikan. Hal ini 
menyebabkan mereka mengalami krisis motivasi, keinginan dan kebutuhan pendidikan yang berujung pada rendahnya kualitas dan kuantitas pengetahuan masyarakat yang berkarakter dan berdaya saing. "Kampung Pendidikan" merupakan sebuah wadah yang kompleks untuk prosespendidikan dengan melibatkan berbagai pihak seperti keluarga, sekolah, dan masyarakat yang dikenal sebagai tripusat pendidikan dengan bernuansa pada muatan lokal. Desain pendidikan ini digunakan sebagai strategi untuk meningkatkan pengetahuan dalam membangun perberdayaan partisipasi masyarakat yang berakarakter dan berdaya saing. Menawarkan 3 program yaitu : DIDIKMASYARAKAT (Kolaborasi dan Sinergi)DIDIKPEMUDA (Berpikir Global, Bertindak Lokal), DIDIKKAMPUNG.Ketiga program tersebut diharapkan mampu mengembangkan potensi desa, yaitu sumber daya manusia yang berdampak untuk pengembangan sumber daya alam. Berdasarkan penelitian di desa Kuajang Kecamatan Binuang Kabupaten Polewali Mandar, Sulawesi Barat, Kampung Pendidikan sangat diharapkan kehadirannya untuk mewadahi potensi masyarakat setempat.

\section{SARAN}

Berdasarkan penelitian ini diharapkan Kampung Pendidikan dapat terealisasikan dengan baik sebagai salah satu solusi pembangunan desa dan pemberdayaan partisipasi masyarakat desa berkarakter dan berdaya saing. Tidak menutup kemungkinan jika beberapa hal diatas dilakukan, yaitu antara lain adalah membangun SDM Desa, membekali masyarakat Desa dengan Iptek, membangun Pasar Desa serta mendorong tumbuhnya Pengusaha Pemula Desa yang berbasis teknologi maka ekonomi desa akan tumbuh produktif dan terjadi lompatan pendapatan yang tinggi. Pada gilirannya Desa akan memiliki kekuatan dan daya saing yang dapat memberikan dampak pada daya saing nasional. Untuk itu diperlukan inovator-inovator pemuda lainnya untuk membangun desa berbasiskan Kampung Pendidikan

\section{DAFTAR PUSTAKA}

Abed, Muhammad al Jabiri. 2000. Post Tradisionalisme Islam. LKiS. Yogyakarta.

Ary H, Gunawan. 2000. Sosiologi Pendidikan. PT. Rineka Cipta. Jakarta. Yahya Khan. 2010. Pendidikan Karakter Berbasis Potensi Diri Mendongkrak Kualitas Pendidikan. Pelangi Publishing. Yogyakarta.

Boeree, C. G. (2009). Metode Pembelajaran dan Pengajaran. Arr-ruzz Media Grup. Bandung.

Kartasasmita B. 2010. Pneumonia pada Balita. Kemenkes RI. Jakarta.

Notoatmodjo, S. 2010. Pendidikan dan Perilaku Kesehatan. Rineka Cipta. Jakarta.

Saroni, Muhammad. 2011. Manajemen Sekolah Kita Menjadi Pendidik Yang Kompeten. Ar-Ruzz Media, Yogyakarta.

Sjarkawi. 2008 . Membentuk Kepribadian Anak "Peran Moral Intelektual, Emosional, dan Sosial Sebagai Wujud Integritas Membangun Jati Diri”. PT. Bumi Aksara. Jakarta.

Soekanto, Soerjono. , 2006. Sosiologi Suatu Pengantar. PT. Raja Grafindo Persada, Jakarta

Suhendra. 2006.Peranan Birokrasi dalam Pemberdayaan Masyarakat. Alfabeta.Bandung.

Undang - Undang Nomor 6 Tahun 2014 Tentang Desa, Lembaran Negara Republik Indonesia Tahun 2014 Nomor 7, Tambahan Lembaran Negara Nomor 5495.

Yahya Khan. 2010. Pendidikan Karakter Berbasis Potensi Diri Mendongkrak Kualitas Pendidikan. Pelangi Publishing. Yogyakarta. 